Open Access

\title{
The mediating effect of microfinancing on access to finance and growth of microenterprises: evidence from the Philippines
}

\author{
Imelda T. Angeles ${ }^{* *}$ (D) Ma. Socorro P. Calara ${ }^{2}$ and Allan B. de Guzman ${ }^{2}$
}

\author{
* Correspondence: imelda.angeles@ \\ ust.edu.ph \\ 'University of Santo \\ Tomas-Graduate School, Espana \\ Boulevard, 96 15th Avenue, \\ Barangay San Roque, Quezon City, \\ Manila, Philippines \\ Full list of author information is \\ available at the end of the article
}

\begin{abstract}
Undoubtedly, microenterprises play a critical role in the development of the economy. Comprising a dominant share in the industry, microenterprises help to alleviate poverty and unemployment. However, the growth of microenterprises remains a global challenge. A number of scholars have attributed the growth of microenterprises to accessibility of finance; however, microfinancing is equally significant in the initiative of owners to expand. This study aims to examine how microfinancing mediates the effect of access to finance on the growth of microenterprises. A survey result from a dataset of 582 microenterprises from the Philippines was used for correlation, regression, and mediation analyses. The results suggest that the impact of access to finance on the growth of microenterprises is heightened when microfinancing is maximized. However, the owners' preferences toward internal financing limit the ability to expand. Thus, the issue of stagnation is a result of the owners' isolation to external financing. The results highlight the need for a more holistic approach to enterprise growth than merely facilitating access to finance. The study recommends aspects such as literacy and competitiveness as factors other than access to capital as enablers of growth. The results may challenge policymakers to enhance the existing policy frameworks further and provide more skills-enhanced income opportunities. Further, an experimental research using an intervention may help discover how to overcome stagnancy of micro and small firms.
\end{abstract}

Keywords: Microenterprises, Microfinancing, Access to finance, Microenterprise growth

\section{Introduction}

Over the years, microenterprises have been a vital agent of economic development (Acs, Desai, \& Hessels, 2008; Koster \& Rai, 2008; Le, Nguyen-Lisovich, \& Raven, 2016; Naude, 2010, 2011; Stel, Carree, \& Thurik, 2005). Comprising a significant percentage of business establishments, microenterprises and small firms drive growth by reducing poverty, providing alternative employment to urban and rural communities, and creating jobs (Wang, 2016). However, despite their dominant share in the business industry, microenterprises worldwide are hampered by constrained growth.

Previous studies have indicated that not all firms grow; microenterprises and small firms are contained within sustainability and are not progressing toward productivity,

(c) The Author(s). 2019 Open Access This article is distributed under the terms of the Creative Commons Attribution 4.0 International License (http://creativecommons.org/licenses/by/4.0/), which permits unrestricted use, distribution, and reproduction in any medium, provided you give appropriate credit to the original author(s) and the source, provide a link to the Creative Commons license, and indicate if changes were made. 
income, and employment generation (Berner, Gomez, \& Knorringa, 2008). Reeg (2013), for his part, averred that microenterprises in developed and developing countries are stagnating. The barriers to growth faced by micro and small enterprises are at the center of discussion among scholars. Notably, empirical studies have identified access to finance as one of the many factors constraining the growth of microenterprises and small firms (Aldaba, 2011; Beck, Lu, \& Yang, 2015; Prohorovs \& Beizitere, 2015). Further, the insufficiency of capital is believed to be the primary factor preventing microenterprises and small firms from reaching their full potential (Fowowe, 2017). Additionally, the lack of capital hinders the growth opportunities of small firms (Fowowe, 2017).

In response to the insufficiency of capital, several solutions had been initiated in various countries. In Sri Lanka, the government supports microenterprises by providing capital through grants (Fafchamps, McKenzie, Quinn, \& Woodruff, 2011). In Namibia and Germany, loans are given at a discount and with low repayment rates, but literacy in management skills is the responsibility of the borrower (Hampel-Milagrosa, 2014). A study of microenterprises in Asian countries, including India and the Philippines, shows that microlending companies provide capital to microenterprises (Fafchamps et al., 2011).

The Philippines is no exemption to the challenges of growth and development of microenterprises. The growth pattern of microenterprises in the Philippines continues to outnumber small, medium, and large enterprises. However, despite the considerable proportion, microenterprises have remained stagnant in their progression to small and medium enterprises (Aldaba, 2011; Hampel-Milagrosa, 2014). There is an observed declining pattern in the number of microenterprises from 2008 to 2010. This structure of microenterprises prompted the government to create a program to support growth and expansion (Hampel-Milagrosa, 2014). In 2010, the government has initiated several financing programs to support the capital needs of the small firm owners. The dramatic increase of $22 \%$ in the number of microenterprises from 2010 to 2012 may have resulted from the massive government program to fund microenterprise start-ups through microfinance and small-scale enterprise programs. The government allocated funds to support the capital requirements of small-scale enterprises, including microenterprises and small firms (ADB, 2014). This provision aims to support microenterprises to increase their production and income. However, over time, the growth patterns became constant if not, declining in the number of micro and small firms. The after effect of the programs suggests that the funding have helped in the short run; however, it did not sustain microenterprises in the long term.

The literature has sufficient evidence to support that firm financing and access to finance are important keys to the development of microenterprises; however, there is not much evidence to support the mediating effect of microfinancing on the relationship of access to finance and growth of microenterprises especially in the context of a developing country like the Philippines. This research purports to examine the gap between access to finance and microenterprises' growth and why the former failed to achieve growth given the opportunity of microfinancing, and ascertain the mediating effect of microfinancing on the effect of access to finance on microenterprise growth.

The study conducted two sets of analyses. The descriptive analysis outlines the composition of owners' microfinancing, while the inferential analysis examines the mediating effects of microfinancing on access to finance and growth of 
microenterprises. The results of the study can help assess the seemingly slow growth of microenterprise in the country despite the availability of finance. The study contributes to the literature in two ways: first, the results may challenge policymakers to enhance the existing policy frameworks and provide more skills-enhanced income opportunities. Second, it may encourage an experimental study using an intervention to further discover ways to enhance the growth of micro and small enterprises.

\section{Literature review}

\section{Growth of microenterprises}

Microenterprise is described to be a small business with fewer employees and a small capital requirement (Rhyne, Otero, 1992). In most developing countries, microenterprises serve as an engine of growth by overcoming unemployment and alleviating poverty. As microenterprises and small firms comprise a dominant part in the market, their growth has not been evident, neither has the existence been contributing and impacting the economy (Simeon \& Lara, 2005). This paper argues that financing plays a very important role in sustaining the operation of businesses, but its effect is not enough to enable expansion. According to Mead and Liedholm (1998), the transition of growth from microenterprises to small and medium firms is negligible. Arguments were raised regarding the factor contributing to the growth of microenterprises and small firms. Several scholars disputed that access to finance is considered a major factor constraining growth (Aldaba, 2011; Beck et al., 2015; Prohorovs \& Beizitere, 2015); conversely, Simeon and Lara (2005) argued that capabilities and opportunities have a larger influence on achieving growth. In contrast, many authors look at the behavioral responses of the owners when capital is given (Demirguc-Kunt, Beck, \& Honohan, 2008). This could mean that the owners' partiality towards either distributing resources on productivity or not, may have an effect on the growth of small firms.

\section{Access to finance and microfinancing}

Access to finance is the ability of the small enterprise to avail financial services, including credit and savings. The body of literature has found that access to finance promotes growth through financial services and financing. Rupeika-Apoga (2014) rationalized the significance of access to finance on the development of the firm. Levine (2005) reiterated a general perspective that "finance does not cause growth; finance responds to changing demands from the real sector." In contrast, the availability of finance to firms is what determines business growth. Literature claimed that access to finance is a major constraint in achieving microenterprise growth (Aldaba, 2013; Ayyagari, Demirguc-Kunt, \& Maksimovic, 2008; Beck \& Demirguc-Kunt, 2006; Beck et al., 2015; Fowowe, 2017). Consequently, the openness of financial institutions to support the need for capital is critical in overcoming the growth constraint of microenterprises (Khandker, Samad, \& Ali, 2013; Kuzilwa, 2005).

While microfinancing is vital in the investment and expansion of microenterprises and small firms (Aldaba, 2011), the utilization of capital may be another cause of growth constraint among micro and small firms. Microfinancing is indicated by the 
sources of capital of the small firm owners. Armendáriz and Morduch (2010) defined microfinancing as access to financial services to benefit low-income borrowers by providing capital to microenterprises. Small firm owners can obtain microfinancing from the following four sources: financing from the bank, non-bank sources, own personal savings (and borrowing from friends and relatives), and a combination of these sources. Largely, external financing is assumed to be the biggest source of capital. Krishnaswamy (2007) argued that borrowing capital increases the opportunity of small firms to boost productivity. Beck and Demirguc-Kunt (2006), for their part, posited that banks play a significant role in providing capital for micro, small, and medium enterprises. This notion suggests that bank credit is imperative in supplying reasonable and flexible capital to microenterprises. However, the difficulty of complying with requirements discourages microenterprises from borrowing. The reluctance of banks to support the capital needs of the small firm borrower affects their initiative to grow. Wang (2016) claimed that collateral, processing, and asymmetric information are among the challenges that borrowers have experienced with banks.

Microenterprises find non-bank sources as an alternative to bank credit. Non-bank credit is more open and convenient than bank credit. However, the cost of capital and the mode of payment burden borrowers. As observed by Aldaba (2011) and Bhattacharjee and Rajeev (2014), banks may provide reasonable capital, while non-bank sources may provide convenience but costly capital. The challenge of getting capital from a bank and from non-bank credit persuades the owner to use internal financing. Owners find that using their own money or borrowing from family and friends will save on interest and reduce the complexity of loan processing. The preferential decision to utilize savings is drawn from the pecking order theory (Myers \& Majluf, 1984), which explains that internal financing of the owner is used before accessing external financing. This implies that borrowing takes place after own capital has been consumed. Literature supports the argument that microenterprises and small firms optimize the use of available capital before borrowing (Daskalakis, 2013; Abdulsaleh \& Worthington, 2013). Consequently, the limitation of capital restricts microenterprises and small firms from competing in the market. Thus, this empirical study purports to substantiate the impact of access to finance and microfinancing on the growth of microenterprises.

\section{Research question}

In the growth performance of microenterprises, to what extent do access to finance and microfinancing affect microenterprise growth? How does microfinancing mediate the relationship between access to finance and growth?

From the research question, the following arguments were raised:

H1: Access to finance from bank and non-bank sources has a statistically significant effect on the growth of microenterprises.

H2: Microfinancing from bank, non-bank, own capital, and combined sources has a statistically significant effect on the growth of microenterprises.

H3: The relationship of access to finance with the growth of microenterprises is mediated by microfinancing. 


\section{The hypothesized model}

Figure 1 displayed the mediating effect of microfinancing on the relationship between access to finance and growth of microenterprises. The mediation model proposes that the independent variable influences the mediator variable, which in turn influences the dependent variable. Thus, the mediator variable serves to clarify the nature of the relationship between the independent and dependent variables.

\section{Research methods}

Design

A quantitative approach, using the causal research design, was applied to measure the impact of a condition on the existing phenomena. The process of examination highlighted the mediation analysis of microfinancing on the effect of access to finance on the growth of microenterprises. The objective of the mediation analysis was to seek a deeper understanding of the direct and indirect effects of the independent variable (IV) on the dependent variable (DV) when there is a mediator variable (Agler \& De Boeck, 2017). Since the study is about the impact on growth, the process was expected to change the level of the effect as a result of the mediating variable; thus, the total effect of IV on DV in a normal regression may be found insignificant when mediation analysis is applied. (Kenny \& Judd, 2014). The measurement process included the collection of quantitative data from a sample of 582 microenterprises, drawn from 844,764 (DTI, 2012) listed microenterprises in the Philippines. Participants included microenterprises with a capital of less than P3,000,000 or $\$ 56,000$ and less than 9 employees.

The use of mediating analysis examines the items that indicate the latent variables. As per the notion of Claessens (2006), accessibility of finance demonstrates the availability, reliability, flexibility, and continuity of financial services (Kostov, Arum, \& Annim, 2015). Thus, in the study, accessibility, availability, and accommodation of credit providers indicate access to finance. The accessibility of capital can be provided by bank and non-bank sources; thus, microfinancing refers to the sources of capital as provided by internal and external sources. Internal sources of fund include borrowing from friends and relatives, own savings, and revolving fund of the business. External fund can be sourced from borrowing from bank and non-bank providers. Further, the growth of microenterprises is measured based on the observed change in income, capital, and number of employees. Supported by literature, the growth of microenterprises and small firms is measured in terms of an increase in sales, income, and the number

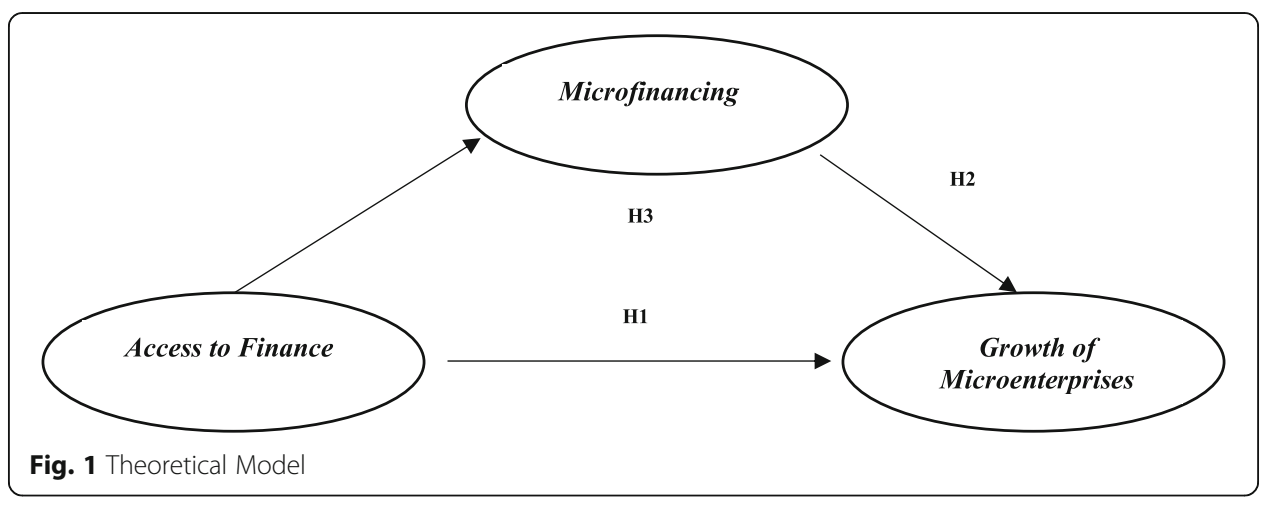


of employees (Mead \& Liedholm, 1998; McPherson, 1996; Rahaman, 2011). Snodgrass and Winkler (2004) added the increase in productivity and profits as determinants of growth.

Items using the nominal and ordinal scales of measurement provided the demographic profiles of the respondents. The survey instruments contained six-point Likert Scale questionnaires to measure respondents' level of agreement and disagreement and their perception of access to microfinancing from capital sources. Microfinancing questions elicited information from microenterprises and small firm owners about their sources of capital. Basic choices were bank, non-bank, and own capital sources. The responses consisting two or more choices were categorized as combined sources of capital. The response on sources of capital was later summarized into internal and external financing. Questions on access to finance were based on indicators predisposed as accessibility, availability, and the accommodation of credit from bank and non-bank credit providers. Questions on the indicators of credit asked participants to indicate their response to each item on a scale ranging from $1=$ strongly disagree to $6=$ strongly agree. Questions on the measurement of growth were indicated by changes in income, capital, products, and the number of employees, classifying changes as $1=$ decreased, 2 = unchanged, and $3=$ increased.

All indicators of the variable were subjected to a reliability test. Cronbach's alpha coefficients were calculated for the scales Microfin_Access_Microgrow and were evaluated using the guidelines suggested by George and Mallery (2016), with $>.9$ excellent, $>.8$ good, $>.7$ acceptable, $>.6$ questionable, $>.5$ poor, and $\leq .5$ unacceptable. The results indicated that the items for Microfin_Access_Microgrow had a Cronbach's alpha coefficient of 0.96 , representing excellent reliability.

To achieve the overall purpose of this study, two sets of examinations were conducted. First, descriptive statistics were generated to summarize the frequencies and statistical differences in variables. Second, the inferential analysis, including a correlation coefficient computation and a mediating analysis, as achieved from the hypothesized model, was conducted. The analysis included the Pearson product-moment $r$ correlation to assess the relationship between the constructs. The Pearson $r$ correlation provides a measure of association (strength) of the relationship between two variables, and the Pearson correlation analysis assumes that the variables have a linear relationship with each other (Conover \& Iman, 1981). The study provided a correlation coefficient matrix of the control variable with the constructs, including the indicators of the independent and dependent variables. Thereafter, a mediation analysis was conducted to assess if microfinancing influences the relationship between access to finance and growth of microenterprises. In the first step, a simple effects model was created, using linear regression, with the growth of microenterprises as the outcome variable and access to finance as the predictor variable. In the second step, a non-interaction model was created by adding microfinancing to the predictor in the linear model in step 1 (the simple effects model). In the third step, an interaction model was created by adding the interaction between microfinancing and access to finance to the predictors in the linear model in step 2 (the non-interaction model). Assumptions for the linear regression analysis were considered for the step 3 model (the interaction model).

Concerning ethical considerations, the researchers explained the objective, mechanics, and the process involved in the research to the participants. A face-to-face 
interaction with the respondents guided the respondents who are taking the survey. Respondents voluntarily participated in the activity without any force or threat from the researchers. The researchers assured the participants of confidentiality and non-disclosure of information other than for research purposes.

\section{Results and findings}

Descriptive statistics

Respondents' profile

Frequencies and percentages were calculated to describe the attributes of the respondents who participated in the study.

Table 1 shows the characteristics of the respondents. The results show that female owners comprised a higher percentage of ownership (60\%) than men, indicating that women are more inclined to engage in business than men. The age of the owners are between 35 and 44 years old; these owners comprised $28 \%$ of the sample. The age may indicate the level of maturity of the owner to invest in goods and services. Sixty-two percent of owners were married and presumed to be the breadwinners of their families. Additionally, $48 \%$ were college graduates, indicating that microenterprise may be an alternative to the difficulty in finding employment. Moreover, $61 \%$ of microenterprises were family owned, with $41 \%$ operating from home. The result indicates that running a microbusiness is for convenience and practicality on the part of the owners who have limited capital. Forty percent of the businesses had been operating for 2 to 5 years, indicating that firms are within the starting up or within the survival period.

Table 1 Demographic characteristics of the microenterprises

\begin{tabular}{llllll}
\hline Control variables & $N=582$ & $\%$ & Category & $N=582$ & Percentage \\
\hline Gender & 352 & 60 & Age of Firm & \\
Female & 230 & 40 & 2-5 year & 85 & 15 \\
Male & & & 6-10 years & 224 & 38 \\
& & & More than 10 years & 114 & 20 \\
& 582 & $100 \%$ & Total & 27 \\
Total & & & Educational accomplishment & $100 \%$ \\
Age of the Owner & 68 & 12 & Elementary graduate & 35 & 6 \\
$15-24$ & 125 & 20 & HS level & 30 & 5 \\
$25-34$ & 161 & 28 & HS graduate & 115 & 20 \\
$35-44$ & 143 & 25 & Vocational & 39 & 7 \\
$45-54$ & 68 & 12 & College level & 84 & 14 \\
$55-64$ & 17 & 3 & College graduate & 279 & 48 \\
65 and Over & 582 & $100 \%$ & Total & 582 & $100 \%$ \\
Total & & & Ownership & & \\
Civil Status & 160 & 27 & Family owned & 353 & 61 \\
Single & 363 & 62 & Individually owned & 169 & 29 \\
Married & 59 & 11 & With partner & 60 & 30 \\
Separated and widow & 582 & $100 \%$ & Total & 582 & $100 \%$ \\
Total & & & &
\end{tabular}




\section{Summary statistics}

Summary statistics were calculated for each interval and ratio variable. Frequencies and percentages were calculated for each nominal and ordinal variable.

Figure 2 displays the distribution of the sources of capital utilized by the small firms. The results show that internal financing is the most frequently observed source of capital $(n=239,42 \%)$. The combined sources represent capital from two or more resources, which accounts for the second most observed source of capital $(n=184$, 33\%). The results in Table 2 show observations of how the operation moves within a period. Owners observed an average change of income of 2.64 within a period indicating a minimal increase in the profitability. The observations for change in capital had an average of 2.59, indicating a minimal increase in capital. The observations for change in products had an average of 2.56 , indicating a minimal increase in products. The observations for change in the number of employees indicated an average increase of 2.45. In summary, microenterprises witnessed a minimal increase in the growth performance of the firm. Among the indicators of growth, change in income takes a higher observation of increase when compared to the other indicators.

Table 2 further displays the perceived accessibility of finance as observed by the owners. The observations for access of capital from the bank had an average of 3.59, indicating that a bank is visible and available in the community. The observations for access from the non-Bank had a higher agreement of 4.01, indicating that a non-bank is not only visible, but it is also accessible and available to the owners. The result implies that owners find it easier to get capital from the non-bank credit than from the bank.

\section{Inferential analysis}

\section{Correlation coefficients}

A Spearman correlation analysis was conducted among control variables, microfinancing, access to finance, and growth of microenterprises. The Cohen's standard was used to evaluate the strength of the relationships, where coefficients between .10 and .29 represent a small effect size, coefficients between .30 and .49 represent a moderate

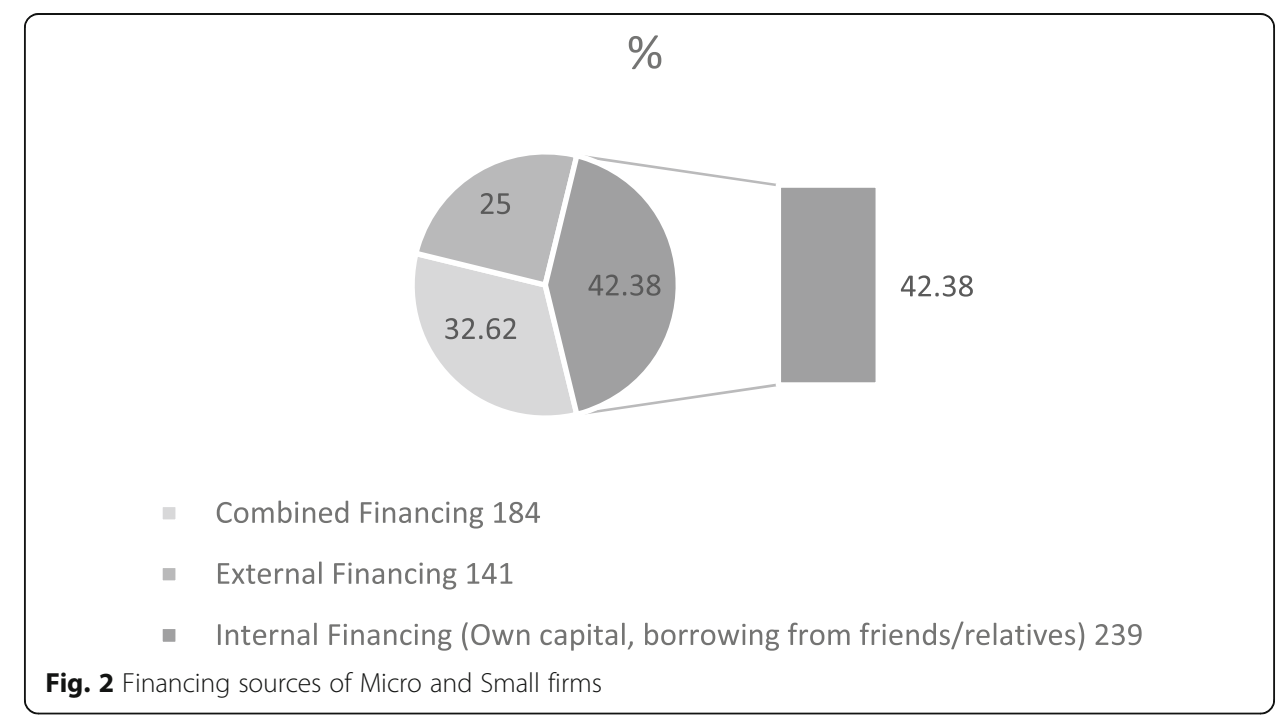


Table 2 Summary statistics of owner's observation on the change in the performance of the firm and perceived accessibility of capital from bank and non-bank sources

\begin{tabular}{lllllll}
\hline Indicators & $\mathrm{M}$ & $\mathrm{SD}$ & Number & $\mathrm{SE}_{\mathrm{M}}$ & Skewness & Kurtosis \\
\hline Growth of Microenterprises & & & & & & \\
$\quad$ Change in income & 2.64 & 0.59 & 582 & 0.02 & -1.41 & 0.95 \\
$\quad$ Change in capital & 2.59 & 0.59 & 582 & 0.02 & -1.12 & 0.24 \\
$\quad$ Change in products & 2.56 & 0.60 & 582 & 0.03 & -1.04 & 0.05 \\
$\quad$ Change in the number of employees & 2.45 & 0.58 & 582 & 0.02 & -0.48 & -0.71 \\
Access to finance & & & & & & \\
$\quad$ Access-bank & 3.59 & 1.51 & 582 & 0.06 & -0.32 & -0.92 \\
$\quad$ Access-non-bank & 4.01 & 1.51 & 582 & 0.06 & -0.55 & -0.51 \\
\hline
\end{tabular}

"-" indicates that the sample size is too small to calculate the statistic

effect size, and coefficients above .50 indicate a large effect size (Cohen, 1988). Table 3 displays the correlation of the control variables with microfinancing, access to finance, and growth of microenterprises.

Table 3 displays the relationship indicating a positive significant relationship between age $(r=.18 ; p=<.001)$, civil status $(r=.19 ; p=<.001)$, age of firm $(r=.16 ; p=<.001)$, and access to finance. The result indicates that a one-unit increase in age, civil status, and age of firm increases access to finance. There is a negative significant relationship between community $(r=.014 ; p=<.001)$ and location $(r=-0.10 ; p=<.05)$. The result indicates that a one-unit increase in community and location decreases access to finance.

Table 4 shows the correlation of the control variables with the average growth of microenterprises. The results display a positive significant relationship between civil status $(r=.08 ; p=<0.05)$, educational attainment $(r=.010 ; p=<0.05)$, and average growth. The result implies that a one-unit increase in civil status and education increases the average growth. There is a negative significant correlation between gender $(r=0.08 ; p=<0.05)$, community $(r=-0.17 ; p=<.001)$, and average growth, indicating

Table 3 Spearman correlation matrix among age, CS, HEA, AGEF, gender, community, ownership, location, BUSACT, and ACCESS_FIN

\begin{tabular}{lllllllllll}
\hline Variable & 1 & 2 & 3 & 4 & 5 & 6 & 7 & 8 & 9 & 10 \\
\hline 1. Age & - & & & & & & & & \\
2. CS & 0.56 & - & & & & & & & \\
3. HEA & -0.02 & -0.09 & - & & & & & & \\
4. AGEF & 0.33 & 0.23 & -0.02 & - & & & & & \\
5. Gender & -0.00 & -0.05 & 0.09 & 0.08 & - & & & & \\
6. Community & -0.11 & -0.14 & 0.35 & 0.02 & 0.22 & - & & & \\
7. Ownership & -0.10 & -0.06 & 0.06 & -0.03 & 0.08 & 0.05 & - & & \\
8. Location & -0.05 & 0.02 & 0.04 & 0.14 & 0.06 & 0.13 & 0.18 & - & \\
9. BUSACT & -0.03 & -0.06 & 0.04 & -0.21 & -0.02 & 0.06 & -0.13 & -0.15 & - \\
10. ACCESS_FIN & 0.18 & 0.19 & -0.04 & 0.16 & -0.07 & -0.14 & -0.02 & -0.10 & -0.08 & - \\
\hline
\end{tabular}

The critical values are $0.08,0.11$, and 0.14 for significance levels $.05, .01$, and .001 , respectively CS civil status, HEA highest educational attainment, AGEF the age of the firm, BUSACT the business activity, AVEGROW the average growth of the microenterprises 
Table 4 Spearman correlation matrix among age, CS, HEA, AGEF, gender, community, ownership, location, BUSACT, and AVEGROW

\begin{tabular}{|c|c|c|c|c|c|c|c|c|c|c|}
\hline Variable & 1 & 2 & 3 & 4 & 5 & 6 & 7 & 8 & 9 & 10 \\
\hline 1. Age & - & & & & & & & & & \\
\hline 2. CS & 0.56 & - & & & & & & & & \\
\hline 3. HEA & -0.02 & -0.09 & - & & & & & & & \\
\hline 4. AGEF & 0.33 & 0.23 & -0.02 & - & & & & & & \\
\hline 5. Gender & -0.00 & -0.05 & 0.09 & 0.08 & - & & & & & \\
\hline 6. Community & -0.11 & -0.14 & 0.35 & 0.02 & 0.22 & - & & & & \\
\hline 7. Ownership & -0.10 & -0.06 & 0.06 & -0.03 & 0.08 & 0.05 & - & & & \\
\hline 8. Location & -0.05 & 0.02 & 0.04 & 0.14 & 0.06 & 0.13 & 0.18 & - & & \\
\hline 9. BUSACT & -0.03 & -0.06 & 0.04 & -0.21 & -0.02 & 0.06 & -0.13 & -0.15 & - & \\
\hline 10. AVEGROW & 0.01 & 0.08 & 0.10 & -0.04 & -0.08 & -0.17 & 0.00 & 0.06 & -0.03 & - \\
\hline
\end{tabular}

The critical values are $0.08,0.11$, and 0.14 for significance levels $.05, .01$, and .001 , respectively

that a one-unit increase in gender and community is likely to decrease the growth of microenterprises.

\section{Linear regression}

There are three analyses presented in Table 5 . The results of the linear regression model of the indicators of microfinancing shows a significant effect, with $F(2,574)=11.08, p<.001$, and $R^{2}=0.04$, indicating that approximately $4 \%$ of the variance in average growth (AVEGROW) is explainable by microfinancing. The external financing category of microfinancing significantly predicted AVEGROW, with $B=-0.25, t(574)=-4.67$, and $p<.001$. The negative coefficient suggests that capital provided by the bank has an inverse effect on the growth of microenterprises. In contrast, the internal financing category of microfinancing did not significantly predict AVEGROW, with $B=-0.09, t(574)=-1.82$, and $p=.069$. The result suggests that capital provided by savings or borrowing from friends is not contributing to the growth of microenterprises.

The result of the linear regression model between microfinancing and the growth of microenterprises were significant, with $F(1,562)=17.70, p<.001$, and $R^{2}=0.03$,

Table 5 Results for linear regression, with microfinancing and access to finance predicting the growth of microenterprises

\begin{tabular}{lllllll}
\hline Variable & $\mathrm{B}$ & $\mathrm{SE}$ & $95 \% \mathrm{Cl}$ & $\beta$ & $t$ & $p$ \\
\hline (Intercept) & 2.63 & 0.04 & {$[2.56,2.70]$} & 0.00 & 74.22 & $<.001$ \\
Microfin-external financing & -0.25 & 0.05 & {$[-0.35,-0.14]$} & -0.24 & -4.67 & $<.001$ \\
Microfin-internal financing & -0.09 & 0.05 & {$[-0.18,0.01]$} & -0.08 & -1.82 & .069 \\
(Intercept) & 2.32 & 0.06 & {$[2.20,2.44]$} & 0.00 & 38.04 & $<.001$ \\
Microfinancing & 0.08 & 0.02 & {$[0.04,0.12]$} & 0.17 & 4.21 & $<.001$ \\
(Intercept) & 2.46 & 0.06 & {$[2.34,2.57]$} & 0.00 & 42.26 & $<.001$ \\
Access To Finance & 0.03 & 0.01 & {$[-0.00,0.06]$} & 0.08 & 1.88 & .061 \\
\hline
\end{tabular}

Results: $F(2,574)=11.08, p<.001, R^{2}=0.04$

Unstandardized regression equation: AVEGROW $=2.63-0.25 \times$ Microfin-external financing $-0.09 \times$ Microfin-internal financing

Results: $F(1,562)=17.70, p<.001, R^{2}=0.03$

Unstandardized regression equation: AVEGROW $=2.32+0.08 \times$ Microfinancing

Results: $F(1,562)=3.52, p=.061, R^{2}=0.01$

Unstandardized regression equation: $A V E G R O W=2.46+0.03 \times$ Access to finance 
indicating that approximately $3 \%$ of the variance in AVEGROW is explainable by microfinancing. Microfinancing significantly predicted AVEGROW, with $B=0.08, t$ $(562)=4.21$, and $p<.001$. This indicates that, on an average, when there is an increase in the sources of capital, there is an expected effect on the growth of microenterprises. The result supported hypothesis 2 stating that microfinancing predicts the growth of microenterprises.

The results of the linear regression model between access to finance and growth of microenterprises were not significant, with $F(1,562)=3.52, p=.061$, and $R^{2}=0.01$, indicating that access did not explain a significant proportion of variation in AVEGROW. The result implies that access to finance is not a factor of growth of microenterprises. Thus, hypothesis 1 which states that access to finance predicts the growth of microenterprises is not supported.

\section{Mediation analysis}

A Baron and Kenny mediation analysis was conducted to assess if microfinancing mediated the relationship between access to finance and the growth of microenterprises. Three regressions were conducted to determine whether the data supported a mediating relationship. For mediation to be supported, the following four conditions must be met: (1) the independent variable must be related to the dependent variable, (2) the independent variable must be related to the mediator variable, (3) the mediator must be related to the dependent variable while in the presence of the independent variable, and (4) the independent variable should no longer be a significant predictor of the dependent variable in the presence of the mediator variable (Baron \& Kenny, 1986). In this analysis, the independent variable is access to finance, the mediator is microfinancing, and the dependent variable is AVEGROW. The linear regression of access to finance on the growth of microenterprises computed in Table 4 will not be necessary when the mediation analysis takes place (Kenny \& Judd, 2014).

Table 6 exhibits the mediation result. First, the regression with access to finance predicting AVEGROW was conducted. The regression of AVEGROW on access to finance was significant, with $F(2,580)=4.79$ and $p=.029$. The results show that access to finance was a significant predictor of AVEGROW, with $B=0.04$, indicating that the first criterion for mediation was satisfied. Second, the regression with access to finance predicting microfinancing was conducted. The regression of microfinancing on access was significant, with $F(2,580)=14.65$ and $p<.001$. The results showed that access to

Table 6 The mediation effect of microfinancing on the relationship between access to finance and growth of microenterprises

\begin{tabular}{llllll}
\hline Dependent & Independent & B & SE & $t$ & $p$ \\
\hline $\begin{array}{l}\text { Regression 1 } \\
\text { AVEGROW }\end{array}$ & Access & 0.04 & 0.02 & 2.19 & .029 \\
$\begin{array}{l}\text { Regression 2 } \\
\text { Microfinancing }\end{array}$ & Access & 0.12 & 0.03 & 3.83 & $<.001$ \\
$\begin{array}{l}\text { Regression 3 } \\
\text { AVEGROW }\end{array}$ & Access & & & & \\
& Microfinancing & 0.02 & 0.02 & 1.51 & .133 \\
& & 0.10 & 0.02 & 4.39 & $<.001$ \\
\hline AVEGROW the growth of microenterprises, ACCESS access to finance, MICROFINSOURCES microfinancing
\end{tabular}

AVEGROW the growth of microenterprises, ACCESS access to finance, MICROFIN_SOURCES microfinancing 
finance was a significant predictor of microfinancing, with $B=0.12$, indicating that the second criterion for mediation was satisfied. Next, the regression with access to finance and microfinancing predicting AVEGROW was conducted. The regression of AVEGROW on access to finance and microfinancing was significant, with $F(3,579)=12.12$ and $p<.001$, suggesting that access to finance and microfinancing accounted for a significant amount of variance in AVEGROW. The individual predictors were examined further. The results show that microfinancing was a significant predictor of AVEGROW when access was included in the model, with $B=0.10$, indicating that the third criterion for mediation was satisfied. The results further show that access to finance was not a significant predictor of AVEGROW when microfinancing was included in the model, with $B=0.02$, indicating that the fourth criterion for mediation was satisfied. Since all four criteria were satisfied, a complete mediation is supported. The result supported $\mathrm{H} 3$ which states that the relationship between access to finance and the growth of microenterprises is mediated by microfinancing.

\section{Discussion}

The study analyzed the growth of microenterprises, with the objective of examining the effect of access to finance, microfinancing, and growth of microenterprises using a mediation analysis. The study attempted to examine the factors that constrained the growth of small firms. The discussion on the results is aligned with the current argument among scholars on the effect of access to finance on growth. The body of literature posited that access to finance is the most identified factor that has constrained growth (Wang, 2016), implying that access to finance plays a significant role in the growth of microenterprises and small firms. The result of the study has added that microfinancing mediates the effect of access to finance on the growth of microenterprises.

The result of the mediation analysis revealed that microfinancing intervenes the effect of access to finance on growth. On one hand, microfinancing is sourced in the following three ways: external financing, internal financing, and combined sources of capital. The result suggests that microfinancing intensifies the effect of access to finance when financing is maximized by the owners. In the study, small firm owners fail to utilize the availability of capital provided by the bank and non-bank sources. By failing to utilize the external financing, microenterprises are restricting the growth by limiting opportunities with the available capital on hand. The result is supported by Ayyagari et al. (2008) claiming that finance becomes a hindrance to growth when small firms do not maximize the availability of capital from bank and non-bank sources. This is evident from the results, which depict lower financing from banks. Non-bank sources may be higher because of the convenience, but over time, the high cost of capital results to liabilities instead of opportunities. The preference of the owners toward non-bank financing collaborates with Aldaba (2013) who posited that isolation of owners from the bank is a result of restrictions imposed by banks on extending loans to non-collateralized credit. The result contradicts the findings of Beck et al. (2015) who claimed that financing from informal sources has a higher effect on microenterprise growth when compared to borrowing from banks. While non-bank sources provide convenience in obtaining capital, the high cost of interest weakens the potential to maximize income. On enhancing the impact of access to finance on the growth of 
microenterprise, the results revealed that microenterprises that maximize microfinancing from different sources are likely to influence growth. The results find concurrence with the previous findings concerning why combined sources of capital have a higher impact on growth than other sources. Borrowing from multiple sources can provide a better opportunity for the owners of microenterprises to increase productivity (Krishnaswamy, 2007). Nevertheless, the challenge of stagnation remains in spite of multiple sources of capital.

On the other hand, access to capital may be provided to the owners but the attitude of the owners toward utilization of capital may have an adverse effect on growth. The result is supported by Karlan et al. (2012) who posited the importance of access to finance but noted that its magnitude was not significant to cause growth. Demirguc-Kunt et al. (2008) noted that the owners' behavioral response to the distribution of capital is critical for growth, irrespective of whether it is significant for productivity. Microenterprises might have failed to utilize capital for innovation and expansion. Microenterprises and small firms are geared toward survival and not expansion. The study implies that if microenterprises and small firms increase their capital, but did not use for expansion, then growth remains slow. Thus, microfinancing, coupled with skills and innovation, may have more impact.

The results of the study have the following two implications. First, the complexity of borrowing has led the owners to utilize internal financing, instead of borrowings. The result is supported by the pecking order theory (Myers \& Majluf, 1984), which explains the optimization of internal sources of capital before a decision for external borrowing takes place. Abdulsaleh and Worthington (2013) support this argument, suggesting that microenterprises and small firms maximize the available capital that can be utilized. The results suggest that growth is constrained because of the limited capital obtained from own savings. On the other hand, Webb et al. (2013) observed that the failure of microenterprises to achieve growth is not maximizing the use of capital. The priority of microenterprise owners may be to sustain the business to provide for their family's daily needs, and not for expansion. This notion is supported by Jamak, Ghazali, and Sharif (2017), claiming that microenterprises aim for economic sustenance, and not expansion and growth. Owing to a lack of literacy, owners have the mindset of sustainability instead of growth. According to Alom, Abdullah, Moten, and Azam (2016), a lack of competitiveness is likely to constrain the development of microenterprises, their innovation, and the initiative for growth.

Second, ways other than access to more capital may exist for expanding a business. Skills, management, business opportunities, and innovation may be considered. This notion finds concurrence with the findings of Ibrahim and Shariff (2016) who posited that access to finance contributes to the performance of a firm if it is accompanied by appropriate abilities. The notion compliments Simeon and Lara (2005) who suggested that capabilities and abilities are vital for achieving growth. Donou-Adonsou and Sylwester (2017) added that microfinancing is not enough to grow a business. The expansion of a business must include skills and marketing strategies. This could be the reason why even when small firms obtain more capital but fail to use it appropriately may lead to stagnation.

\section{Conclusion}

Microenterprise growth is an ongoing challenge among developing and developed countries. The purpose of understanding why growth of microenterprises is not 
achieved may be clarified by the result of the study. The study shows that even the availability of finance has not resulted in the development of microenterprises. The mediating effect of microfinancing could result to expansion when access to finance is maximized for investment. The inability to utilize capital for expansion can be attributed to lack of literacy and competitiveness. In contrast, microenterprises do not maximize finance but utilize own capital or interest-free borrowing. The use of internal financing limits the opportunity of the owners to expand the business. The owner's preferences to use internal capital to avoid the consequences of borrowing may develop a mindset of survival, instead of growth.

As a recommendation, motivation and initiative to grow may overcome the sustainability mindset if microenterprises can capitalize on skills rather than on financing. The government and other institutions may enable owners to discover their skills and abilities instead of depending on financing in order to survive. Other factors that may contribute to growth are innovation and technology. These two factors may prove to be of interest for future research. The government may encourage microenterprises and small firms to take the risk of increasing capital and invest into something that will enhance their skills or invest in technology instead of simply sustaining the operation of their businesses. The study may contribute to the body of literature by initiating an experimental research using microfinancing, innovation, and technology as and interventions for growth.

This study has several limitations. First, growth is measured based on the assumption and observation of the owner. An inadequacy of financial records and other information justifies this shortcoming. Second, the sample size may not provide generalizability because of the small percentage compared to the total number of microenterprises in the Philippines. However, for a confidence interval of 4-5, the sample size is acceptable. Further, there is no equality in the distribution of samples from different regions. The growth pattern from microenterprises to small enterprises is not considered. However, the assumption is based on the statistics that small enterprises are the least to grow among small, medium, and large enterprises. The growth pattern of small and medium enterprises may be the focus of future studies.

\footnotetext{
Abbreviations

AGEF: Age of Firm BUSACT-Business Activity; AVEGROW: Average growth; CS: Civil status; HEA: Highest educational attainment
}

Acknowledgements

I would like to extend my sincerest gratitude to Dean Leonardo Canoy, Jr. for his kind and endless support in my endeavor to finish my doctorate program.

Funding

This research did not receive any specific grant from funding agencies in the public, commercial, or not-for-profit sectors.

Availability of data and materials

The data sets used and/or analyzed during the current study are available from the corresponding author on reasonable request.

Authors' contributions

IA, as the corresponding author, mainly conceptualized the objective, the research design, and the model; summarized the literatures from different scholars of the same study; collected, analyzed and interpreted the data; and discussed the implication of the study. MSC has been involved in drafting the manuscript or revising it critically for important intellectual content, review of the content, and revisions of research design deemed necessary. AdG made substantial contributions to the conception and design, revision of the manuscript, and analysis and interpretation of data. The corresponding author and co-authors agreed to be accountable for all aspects of the work in ensuring that questions related to the accuracy or integrity of any part of the work are appropriately investigated and resolved. All authors read and approved the final manuscript. 


\section{Competing interest}

The authors declare that they have no competing interests.

\section{Authors' information}

Asst. Prof. Imelda T. Angeles, the Corresponding Author, is a doctoral candidate from the University of Santo Tomas Graduate School and currently a faculty of UST-College of Commerce and Business Administration. A Certified Public Accountant by practice and Tax Accredited Practitioner, the author is teaching Accounting and Taxation related subjects. She is a researcher of Research Center for Social Sciences and Education of University of Santo Tomas (RCSSED) under Business Rig. She has been into research on topics about Microfinance, Cooperative and Micro and Small Enterprises. University of Santo Tomas Graduate School.

Espana Blvd., Manila, 1005.

Email: imelda.angeles@ust.edu.ph

Tel. No. 781-6629.

Prof. Ma. Socorro P. Calara, a Co-Author, is a professorial lecturer at the Graduate School, University of Santo Tomas, in Manila, Philippines. She handles Business Research courses and serves as a reviewer of both local and international journals dealing with performance management, and entrepreneurship.

University of Santo Tomas Graduate School.

Espana Blvd., Manila, 1005.

Email: mscalara@gmail.com

Tel. No. Tel 731-5396/Fax 740-9732.

Prof. Dr. Allan B. de Guzman, a Co-Author, handles pedagogy, management and research courses at both graduate and undergraduate levels in the University of Santo Tomas. As a prolific writer in educational policy studies, adult learning and teacher education, he has extensively published a total of 132 articles in various ISI-listed journals and at the same time serves as editor, board member and reviewer in international journals. He has received various prestigious awards which included the 2007 SEAMEO-JASPER Research Award given by the Government of Canada and the Southeast Asian Ministers of Education Organization (SEAMEO), the 2006 National Research Council of the Philippines (NRCP)Department of Science and Technology (DOST) Achievement Award and the 2011 Metrobank Foundation Search Most Outstanding Teacher Award in Higher Education, among others. He was the recipient of the 2104 Australian Awards Fellowship on Curriculum Leadership at Queensland University of Technology, Brisbane, Australia. He is currently the Dean of the College of Education, University of Santo Tmas, Manila, Philippines.

University of Santo Tomas College of Education.

Espana Blvd., Manila, 1005.

Email: doc_allan@yahoo.com

Tel. No. Tel 731-4323.

Fax 786-1611 local 8392

\section{Publisher's Note}

Springer Nature remains neutral with regard to jurisdictional claims in published maps and institutional affiliations.

\section{Author details}

'University of Santo Tomas-Graduate School, Espana Boulevard, 96 15th Avenue, Barangay San Roque, Quezon City,

Manila, Philippines. ${ }^{2}$ University of Santo Tomas-Graduate School, Espana Boulevard, Manila, Philippines.

Received: 23 November 2018 Accepted: 28 January 2019

Published online: 11 February 2019

\section{References}

Abdulsaleh, A. M., \& Worthington, A. C. (2013). Small and medium-sized enterprises financing: a review of literature. International Journal of Business and Management, 8(14), 36-54

Acs, Z. J., Desai, S., \& Hessels, J. (2008). Entrepreneurship, economic development and institutions. Small Business Economics, $31(3), 219-234$.

ADB-OECD Study on Enhancing Financial Accessibility for SMEs (2014). Lessons from recent crises. Asian Development Bank and Organisation for Economic Cooperation and Development (pp. 1-198). https://doi.org/https://doi.org/10.1787/ 9789264009257

Agler, R., \& De Boeck, P. (2017). On the interpretation and use of mediation: multiple perspectives on mediation analysis. Frontiers in Psychology, 8(1), 1-11, https://doi.org/https://doi.org/10.3389/fpsyg.2017.01984

Aldaba, R. M. (2011), 'SMEs access to finance: Philippines', in Harvie, C., S. Oum, and D. Narjoko (eds.), Small and Medium Enterprises (SMEs) Access to Finance in Selected East Asian Economies. ERIA Research Project Report 2010-14, (pp.291350). Jakarta: ERIA

Aldaba, R. M. (2013). ASEAN economic community 2015 SME development: narrowing development gap measure. Discussion Paper Series No. 2013-05, 1-16

Alom, F., Abdullah, M. A., Moten, A. R., \& Azam, S. M. F. (2016). Success factors of overall improvement of microenterprises in Malaysia: an empirical study. Journal of Global Entrepreneurship Research, 6(1), 1-13.

Armendáriz, B. \& Morduch, J. (2010). The economics of microfinance. Cambridge, Massachusetts; London, England: MIT Press. 1-29.

Ayyagari, M., Demirgüc-Kunt, A., \& Maksimovic, V. (2008). How important are financing constraints? The role of finance in the business environment. World Bank Economic Review, 22(3), 483-516.

Baron, R. M., \& Kenny, D. A. (1986). The moderator-mediator variable distinction in social psychological research: conceptual, strategic, and statistical considerations. Journal of Personality and Social Psychology, 51(6), 1173-1182.

Beck, T., \& Demirguc-Kunt, A. (2006). Small and medium-size enterprises: access to finance as a growth constraint. Journal of Banking and Finance, 30(11), 2931-2943. 
Beck, T., Lu, L., \& Yang, R. (2015). Finance and growth for microenterprises: evidence from rural China. World Development, 67(4), $38-56$. Berner, E., Gomez, G. M., \& Knorringa, P. (2008). Helping a large number of people become a little less poor: the logic of survival entrepreneurs. UNU WIDER project workshop on entrepreneurship and economic development, Helsinki, 21-23.

Bhattacharjee, M., \& Rajeev, M. (2014). Accessibility to credit and its determinants: a state-level analysis of cultivator households in India. Margin-The Journal of Applied Economic Research, 8(8), 285-300.

Claessens, S. (2006). Access to financial services: a review of the issues and public policy objectives. The World Bank Research Observer, 21(2), 207-240.

Cohen, J. (1988). Statistical power analysis for the behavioral sciences. Hillsdale, New Jersey: Lawrence Erlbaum Associates.

Conover, W. J., \& Iman, R. L. (1981). Rank transformations as a bridge between parametric and nonparametric statistics. American Statistician, 35(3), 124-128.

Daskalakis, N. (2013). Financing practices and preferences for micro and small firms. Journal of Small Business and Enterprise Development, 10(1), 80-101.

Demirgüç-Kunt, A. \& Beck, T.H.L. \& Honohan, P., 2008. "Finance for all?: Policies and pitfalls in expanding access," Other publications TiSEM aec73d3a-d6eb-457f-9182-3, Tilburg University, School of Economics and Management.

Department of Trade and Industry. (2012).Philippines. DTl.gov.ph

Donou-Adonsou, F., \& Sylwester, K. (2017). Growth effect of banks and microfinance: evidence from developing countries. The Quarterly Review of Economics and Finance, 64(2), 44-56.

Fafchamps, M., McKenzie, D., Quinn, S., \& Woodruff, C. M. (2011). When is capital enough to get female microenterprises growing? Evidence from a randomized experiment in Ghana. CSAE Working Paper Series, 2011-11, 59.

Fowowe, B. (2017). Access to finance and firm performance: evidence from African countries. Review of Development Finance, 7(1), 6-17.

George, D., \& Mallery, P. (2016). IBM SPSS Statistics 23 step by step. New York: Routledge.

Hampel-Milagrosa, A. (2014). Micro and small enterprise upgrading in the Philippines: the role of entrepreneur, enterprise, networks and the business environment (pp. 9-138). Bonn: German Development Institute/Deutsches Institut für Entwicklungspolitik.

Ibrahim, M. A., \& Shariff, M. N. M. (2016). Mediating role of access to finance on the relationship between strategic orientation attributes and SMEs performance in Nigeria. International Journal of Business and Society, 17(3), 473-496.

Jamak, A., Ghazali, Z., \& Sharif, M. (2017). Micro-enterprise growth strategies: a conceptual model. Global Business and Management Research: An International Journal, 9(1), 1-12.

Karlan, D., Knight, R., \& Udry, C. (2012). Hoping to win, expected to lose: theory and lessons on microenterprise development. National Bureau of Economic Research. Working paper 18325. http://www.nber.org/papers/w18325. (pp 1-53.)

Kenny, D. A., \& Judd, C. M. (2014). Power anomalies in testing mediation. Psychological Science, 25(2), 334-339.

Khandker, S. R., Samad, H. A., \& Ali, R. (2013). Does access to finance matter in microenterprise growth? Evidence from Bangladesh. Institute of Microfinance Working Paper, 15, 1-49.

Koster, S., \& Rai, S. K. (2008). Entrepreneurship and economic development in a developing country: a case study of India. Journal of Entrepreneurship, 17(2), 117-137.

Kostov, P., Arum, T., \& Annim, S. (2015). Access to financial services: the case of the "Mzansi" account in South Africa. Review of Development Finance, 5(1), 34-42.

Krishnaswamy, K. (2007). Competition and multiple borrowing in the Indian microfinance sector. Institute for Financial Management and Research Centre for Micro Finance Working Paper September 2007. 1-60.

Kuzilwa, J. A. (2005). The role of credit for small business success: a study of the national entrepreneurship development fund in Tanzania. Journal of Entrepreneurship, 14(2), 131-161.

Le, Q. V., Nguyen-Lisovich, M., \& Raven, P. V. (2016). Regional differences in behaviors, attitudes, and motivations related to performance among women-owned microenterprises in Vietnam. World Development Perspectives, 2(4), 17-24.

Levine, R. (2005). Finance and Growth: theory, evidence and mechanisms. In Handbook of Economic Growth, ed. Philippe Aghion and Steven Durlauf. Amsterdam: North Holland.

McPherson, M. A. (1996). Growth of micro and small enterprises in Southern Africa. Journal of Development Economics, 48(2), 253-277.

Mead, D., \& Liedholm, C. (1998). The dynamics of micro and small enterprises in developing countries. World Development, 26(1), 61-74.

Myers, S. C., \& Majluf, N. (1984). Corporate financing and investment decisions when firms have information that investors do not have. Journal of Financial Economics, 13, 187-221.

Naude, W. (2011). Entrepreneurship is not a binding constraint on growth and development in the poorest countries. World Development, 39(1), 33-44.

Naude, W., Naudé, W., \& W., N. (2010). Entrepreneurship, developing countries, and development economics: new approaches and insights. Small Business Economics, 34(1), 1-12.

Prohorovs, A., \& Beizitere, I. (2015). Trends, sources and amounts of financing for micro-enterprises in Latvia. Procedia - Social and Behavioral Sciences, 213(66), 404-410.

Rahaman, M. (2011). Access to financing and firm growth. Journal of Banking \& Finance., 35, 709-723.

Reeg, C. 2013. Micro, small and medium enterprise upgrading in India - learning from success cases. KfW-Development Research. German Development Institute. (pp. 1-229).

Rhyne, E., Otero, M. 1992. Financial services to microenterprises: principles and institutions. World Development.Vol. 20(11)pp1561-1572

Rupeika-Apoga, R. (2014). Access to finance: Baltic financial markets. Procedia Economics and Finance, 9, 181-192.

Simeon, N., \& Lara, G. (2005). Understanding micro and small enterprises growth. USAID, 19-25.

Snodgrass, D. \& Winkler, J.P. 2004. Enterprise growth initiatives: strategic directions and options. Prepared for the U.S. Agency for International Development, Bureau of Economic Growth, Agriculture, and Trade. Final Report, 5-12.

Stel, A. V., Carree, M., \& Thurik, R. (2005). The effect of entrepreneurial activity on national economic growth. Small Business Economics, 24(3), 311-321.

Wang, Y. (2016). What are the biggest obstacles to growth of SMEs in developing countries? An empirical evidence from an enterprise survey. Borsa Istanbul Review, 16(3), 167-176.

Webb, J. W., Morris, M. H., \& Pillay, R. (2013). Microenterprise growth at the base of the pyramid: a resource-based perspective. Journal of Developmental Entrepreneurship, 18(4), 1350026. 